\title{
Impact of cyclic water stress on growth, physiological responses and yield of rice (Oryza sativa L.) grown in tropical environment
}

\author{
Impacto do estresse hídrico cíclico sobre o crescimento, as respostas fisiológicas e \\ rendimento de arroz (Oryza sativa L.)
}

\author{
Nurul Amalina Mohd Zain ${ }^{\mathrm{I}, \text { II }}$ Mohd Razi Ismail ${ }^{\text {I** }}$ Adam Puteh ${ }^{\text {III }}$ \\ Maziah Mahmood ${ }^{\mathrm{IV}}$ M Robiul Islam ${ }^{\mathrm{II}, \mathrm{v}}$
}

\begin{abstract}
A series of water stress cycles [5, 10, 15, 20, 25 and 30 days of irrigation intervel including control flooded $(C F)$, control saturated $(C S)]$ were exposed to investigate the impact of cyclic water stress on growth, physiological responses and yield of a famous Malaysian rice variety, MR220. The study also aimed to determine optimum irrigation schedule for better production of rice. It was observed that grain yield, total biomass, filled spikelet, 1000 grain weight, total panicle, tillers mortality, plant height and number of tillers per plant reduces with increased duration of water stress cycles. Grain yield was higher both in CF and CS condition and those are statistically identical to 5 days of stress cycle or irrigation intervel. The present experiment shows that growth performance and physiological activities of rice differ marginally for 5 days of irrigation difference, exceding that time would reduce yield significantly. The study also showed that proline accumulation and malondialdehyde (MDA) contents in levels increased with increasing duration of water stress cycle. Depending on the findings of the present, it can be stated that rice variety MR220 do not require flooding irrigation and irrigation cycle of 5 days interval is more apprapriate to increase water use and higher yield of rice.
\end{abstract}

Key words: water stress, prolein accumulation, antioxidant enzyme, rice variety MR220.

\section{RESUMO}

Deficiência hídrica com ciclos de 5, 10, 15, 20, 25 e 30 dias de intervalo e irrigação incluindo controle irrigado $(C F)$, controle de saturação (CS)] foram usadas para investigar o impacto do estresse hídrico sobre o crescimento cíclico, fitorespostas fisiológicas e rendimento de variedade de arroz MR220.

\begin{abstract}
O estudo também teve como objetivo determinar o cronograma de irrigação ideal para melhorar a produção de arroz. Observouse que a produção de grãos, biomassa total, spiguetas, 1000-peso de grãos, panículas totais, a mortalidade de perfilhos, altura de planta e número de perfilhos por planta foi reduzida com o aumento da duração do ciclo de estresse hídrico. $O$ rendimento de grãos foi maior tanto na CF e CS condição e foi estatisticamente igual a cinco dias do ciclo de estresse. O experimento mostra que o desempenho do crescimento e atividades fisiológicas de arroz diferem ligeiramente para cinco dias de diferença de irrigação, aumentado esse tempo, reduziria o rendimento significativamente. O estudo também mostrou que o acúmulo de prolina e conteúdo de malondialdeído (MDA) em níveis aumentaram com o increremento da duração do ciclo de estresse hídrico. Pode-se afirmar que a variedade de arroz MR220 não necessita de irrigação e ciclos de irrigação de cinco dias de intervalo é mais apropriado, além de aumentar a utilização de água e assim ter uma maior produção de arroz.
\end{abstract}

Palavras-chave: estresse cíclico de água, acúmulo de prolina, enzimas antioxidantes, arroz.

\section{INTRODUCTION}

Rice (Oryza sativa L.) is one of the three major food crops of the world. Being grown world wide, it is the staple food for more than half of the world's population. It is a nutritious cereal crop, provides $20 \%$ of the total calories and $15 \%$ of protein requirements of world population. Besides being the

Institute of Biological Science, Faculty of Science, University Malaya, Kuala Lumpur, Malaysia.

IIInstitute of Tropical Agriculture, Universiti Putra Malaysia, 43400. Serdang, Selangor Darul Ehsan, Malaysia. E-mail: razi@putra.upm.edu.my.

*Autor para correspondência.

IIIDepartment of Crop Science, Faculty of Agriculture, Universiti Putra Malaysia, Selangor Darul Ehsan, Malaysia.

${ }^{\text {IV }}$ Depatment of Biochemistry, Faculty of Bioctechnology and Biomolecular Science, Universiti Putra Malaysia, Selangor Darul Ehsan, Malaysia.

${ }^{\mathbf{v}}$ Department of Agronomy and Agricultural Extension, Rajshahi University, Rajshahi, Bangladesh. Received 08.28.13 Approved 03.17.14 Returned by the author 08.07.14 CR-2013-1154.R1 
cheapest source of carbohydrate and protein in Asia, it is also a good source of minerals and fibre. Rice straw and bran are important animal feed in many countries. About $92 \%$ of the world's rice is produced and consumed in Asia (HUKE and HUKE, 1997). A majour part of asian rice grown under flooded irrigation where water is the main limiting factor to increase rice production.

The lower productivity of Asian rice in most of the cases is attributed to various abiotic stresses including drought. Drought stress has now become a severe threat to ensure food security in the developing world as well as in Malaysia. Although water is required all over the growth periods of rice plant, there are some critical growth stages when drought stress impacts seriously and create a massive reduction in quantity and quality of yield. Crop responses to drought stress and its tollerence level can be measured by monitoring different physiological changes during drought period (BAJJI et al., 2001). Plant responses to drought is complex and different morphological and biochemical mechanisms are involved within the plants during drought. These mechanisms can be (i) drought escape by rapid development which allows plants to finish there life cycle before severe water stress, (ii) drought avoidance by increasing water uptake and reducing transpiration rate (reduction of stomatal conductance and leaf area) (iii) drought tolerance by maintaining tissue turgor during water stress via osmotic adjustment which allows plants to maintain growth under water stress, and (iv) crop resistance to severe stress through survival mechanisms.

Plants respond to drought stress at the molecular, cellular and physiological levels which vary among species and genotype, length and severity of water stress , crop age and stage of development, organ and cell typ eand sub-cellular compartment (YAMAKAWA et al., 2007). Biosynthesis of proline, is also a well-known osmo-protectant, which is related to the enzyme pyrroline-5-carboxylate synthetase (AUGE \& MOORE, 2002). The water stress resulted in significant decreases in chlorophyll content and the leaf relative water content (NAHER, 2011). The maintenance of high plant water status and plant functions at low water potential, and the recovery of plant function after water stress are the major physiological processes that contribute to the maintenance of high yield under drought stress (BOUMAN \& TUONG, 2001).

To maintain crop productivity under drought stress and ensuring food security, improved cultivation technology should be adopted to increase crop water use efficiency. Malaysia is categorized in zone 3 in terms of water scarcity needing to increase water management efficiency by $25-100 \%$ to meet food requirement by the year 2025. There are many approaches to improve water use efficiency in rice including regulation of irrigation schedule or water stress cycle. Determination of proper water stress cycle is important to increase water use efficiency and rice productivity. Therefore, the objective of the current study was to investigate the impact of cyclic water stress on growth, physiological, biochemical activities and yield of rice vatiety MR220.

\section{MATERIALS AND METHODS}

A famous Malaysian high yielding rice variety, MR220 which is very much susceptable to drought was used for this experiment. Seeds were collected from Gene bank, Malaysian Agricultural Research and Development Institute (MARDI), Malaysia. Seeds were germinated under open rainshelter with transperent plastic shade and normal atmospheric temperature. Seedlings (15 days old) were then transplanted to experimental pot containing $30 \mathrm{~kg}$ soil of Bakau Series $\left(\mathrm{EC}=2.83 \mathrm{dS} \mathrm{m}{ }^{-1} ; \mathrm{pH}=5.1\right)$ in the rainshelter house. Nine (9) healthy seedlings were transplanted in each pot. For proper seedling growth, pots were wattered ragularly upto 30 days after transplanting (DAT). The experiment was conducted in Randomized Complete Block Design (RCBD) with 4 replication. Eight water stress cycles, namely control flooded, control saturated, 5, 10, 15, 20, 25 and 30 days of irrigation intervals were used. Irrigation was applied $10 \mathrm{~cm}$ above the soil surface and for control flooded treatment, this level of water in the pot was maintained contineously. For control saturated treatment, water was applied just to saturate the soil (without flood). Standard (recommended by MARDI) fertilization rate $\left(120 \mathrm{~kg} \mathrm{~N} \mathrm{ha}^{-1}, 80 \mathrm{~kg} \mathrm{~K}_{2} 0\right.$ $\mathrm{ha}^{-1}$ and $70 \mathrm{~kg} \mathrm{P}_{2} \mathrm{O}_{5} \mathrm{ha}^{-1}$ ) and schedule was maintained during the experiment. Determination of plant growth (plant height, number of tillers and number of panicles) was carried out on randomly tagged plants. Tillers mortality (TM) was calculated using the following formula:

$\mathrm{TM}(\%)=[(\mathrm{MT}-\mathrm{P}) / \mathrm{MT} \mathrm{x} 100]$

Where, $\mathrm{MT}=$ Maximum number of tillers and $\mathrm{P}=$ Number of penicles.

Plants were harvested when $70 \%$ of rice shown ripening colour. Grain yield ha-1 was calculated based on KUDOYAROVA et al. (2007), harvest index was calculated based on the ratio between economic yield and total 
biomass production. Water productivity was determine as yield $\left(\mathrm{kg} \mathrm{ha}^{-1}\right) /$ irrigation inflow ( $\mathrm{L}$ $\mathrm{ha}^{-1}$ ). Chlorophyll fluorescence was measured on fully expanded leaf using a portable chlorophyll fluorescence meter (Handy PEA, Hansatech Instruments Ltd., Norwich, UK). Measurements were undertaken at $>3000 \mu \mathrm{mol} \mathrm{m} \mathrm{m}^{-2} \mathrm{~s}^{-1}$ and data's were recorded for 5 seconds. Chlorophyll a $\left(\mathrm{Chl}_{\mathrm{a}}\right)$, chlorophyll b ( $\left.\mathrm{chl}_{\mathrm{b}}\right)$ and total chlorophyll contents of the young expanded leaves were taken at midday and data was calculated following the method of SUSANA et al. (2007). The measurement was obtained from a closed infra-red gas analyzer LICOR 6400 Portable Photosynthesis System (IRGA, Licor Inc., Lincoln, NE, USA) from fully expanded young leaves between 09:00 to 11:00 a.m. Data for net photosynthesis rate $(\mu \mathrm{mol}$ $\mathrm{m}^{-2}-\mathrm{s}^{1}$ ), stomata conductance (micromol $\mathrm{H}_{2} \mathrm{O}$ $\mathrm{m}^{-2} \mathrm{~s}^{-1}$ ) transpiration rate (milimol $\mathrm{m}^{-2} \mathrm{~s}^{-1}$ ), and Instantaneous water use efficiency $\left(\mathrm{molm}^{-2} \mathrm{~s}^{-1}\right.$ water transpired $/ \mathrm{mmolm}^{-2} \mathrm{CO}_{2}^{-1}$ assimilated) was collected during the measurement. Soil moisture content (\%) was determined using soil moisture probe (Model Delta-T Device: Theta-Probe, ML2x) before rewatering of experimental pots and relative water contents in leaves were measured on young fully expanded leaves following the procedure describe in ISLAM et al. (2011). Lipid peroxidation was estimated by measuring the level of malondialdehyde (MDA) production using thiobarbituric acid (TBA) as described by ISLAM et al. (2011). One gram of frozen $(0.25 \mathrm{~mm})$ plant sample was homogenized with a mortar and pestle in $0.5 \%$ trichloracetic acid (TCA, $1 \mathrm{~mL}$ ). The homogenate was centrifuged at $9,000 \mathrm{rpm}$ for $20 \mathrm{~min}$. The supernatant $(0.5 \mathrm{~mL})$ was mixed with $20 \%$ TCA $(2.5 \mathrm{~mL})$ containing
$0.5 \%$ TBA and heated in a boiling water bath for $30 \mathrm{~min}$ and allowed to cool in an quickly ice bath. The supernatant was centrifuged at 9,000rpm for $10 \mathrm{~min}$, and resulting supernatant was used for determination of MDA content using spectrophotometer at $532 \mathrm{~nm}$ wavelength. To determine the accumulation of leaf proline, $0.5 \mathrm{~g}$ of frozen leaf sample was ground in $5 \mathrm{ml}$ ethanol (95\%). Upper zone of the solution was washed with ethanol $(70 \%)$ and centrifuged at $3500 \mathrm{rpm}$ for $10 \mathrm{~min}$ and prolin accumulation was measured on a spectrophotometer at $515 \mathrm{~nm}$ wavelength. The experiment was arranged in a randomized complete block design (RCBD) with eight treatments and four replications. Data was analyzed using SAS software version 9.1 and significant differences among the treatments were compared using Duncan Multiple Range Test (DMRT) at 5\% level of probality.

\section{RESULT AND DISCUSSION}

The water stress have remarkable influence on growth and yield components of rice (Table 1). It was observed that yield, total biomass, filled spikelet, 1000grain weight, total panicle, tillers mortality, plant height and number of tillers reduced with increased duration of water stress cycle. Grain yield was highest under both in continuously flooding (CF) and continously saturated (CS) (10.40 tones $\left.\mathrm{h}^{-1}\right)$ conditions. However grain yield rice yield reduced by $14 \%$ for both 5 and 10 days of water stress cycle compared with $\mathrm{CF}$ and $\mathrm{CS}$. There were no significant difference in total plant biomass between $\mathrm{CF}$, $\mathrm{CS}$ and 5 days of water stress cycle. It was found that 5 days of water stress cycle produce rice

Table 1 - The impact of cyclic water stress on growth and yield components of rice (var. MR220).

\begin{tabular}{|c|c|c|c|c|c|c|c|c|}
\hline $\begin{array}{l}\text { Water } \\
\text { stress } \\
\text { treatments }\end{array}$ & $\begin{array}{l}\text { Plant height } \\
(\mathrm{cm})\end{array}$ & $\begin{array}{l}\text { Number of } \\
\text { tillers / hill }\end{array}$ & $\begin{array}{l}\text { Tillers } \\
\text { mortality } \\
(\%)\end{array}$ & $\begin{array}{l}\text { Total panicle } \\
\text { number } \mathrm{m}^{-2}\end{array}$ & $\begin{array}{l}\text { Filled } \\
\text { spikelet } \\
(\%)\end{array}$ & $\begin{array}{l}1000 \text { grain } \\
\text { weight }(\mathrm{g})\end{array}$ & $\begin{array}{l}\text { Grain yield } \\
\text { (tones } \mathrm{h}^{-1} \text { ) }\end{array}$ & $\begin{array}{l}\text { Total } \\
\text { Biomass } \\
\left(\text { tones } \mathrm{h}^{-1} \text { ) }\right.\end{array}$ \\
\hline $\mathrm{CF}$ & $126.08 \pm 2.55 b$ & $12.75 \pm 1.23^{\mathrm{d}}$ & $2.49 \pm 0.75^{\mathrm{g}}$ & $320.66 \pm 4.56^{\mathrm{d}}$ & $90.13 \pm 0.34^{\mathrm{a}}$ & $23.14 \pm 1.23^{\mathrm{b}}$ & $10.40 \pm 0.34^{\mathrm{a}}$ & $12.13 \pm 0.44^{\mathrm{a}}$ \\
\hline CS & $125.67 \pm 3.45 b$ & $15.75 \pm 1.76^{\mathrm{a}}$ & $4.47 \pm 0.79^{f}$ & $422.31 \pm 5.45^{b}$ & $90.18 \pm 2.31^{\mathrm{a}}$ & $23.51 \pm 1.54^{\mathrm{b}}$ & $10.41 \pm 0.21^{\mathrm{a}}$ & $12.18 \pm 1.21^{\mathrm{a}}$ \\
\hline $5 \mathrm{WSC}$ & $138.30 \pm 5.67 \mathrm{a}$ & $14.83 \pm 3.41^{\mathrm{b}}$ & $13.39 \pm 1.34^{\mathrm{e}}$ & $278.51 \pm 6.56^{\mathrm{e}}$ & $90.51 \pm 1.11^{\mathrm{a}}$ & $25.23 \pm 2.45^{\mathrm{a}}$ & $8.91 \pm 2.13^{\mathrm{b}}$ & $12.88 \pm 0.45^{a}$ \\
\hline $10 \mathrm{WSC}$ & $117.50 \pm 6.75 \mathrm{c}$ & $13.67 \pm 3.32^{\mathrm{c}}$ & $16.69 \pm 2.45^{\mathrm{d}}$ & $447.93 \pm 4.45^{\mathrm{b}}$ & $83.07 \pm 2.12^{\mathrm{b}}$ & $23.74 \pm 2.13^{\mathrm{c}}$ & $8.91 \pm 2.14^{\mathrm{b}}$ & $11.64 \pm 1.34^{\mathrm{b}}$ \\
\hline 15 WSC & $107.13 \pm 6.32 \mathrm{c}$ & $13.67 \pm 3.56^{\mathrm{c}}$ & $26.48 \pm 1.78^{\mathrm{c}}$ & $521.49 \pm 2.45^{\mathrm{a}}$ & $44.14 \pm 1.56^{\mathrm{c}}$ & $14.89 \pm 1.23^{\mathrm{d}}$ & $3.29 \pm 0.45^{\mathrm{c}}$ & $9.57 \pm 1.77^{\mathrm{c}}$ \\
\hline $20 \mathrm{WSC}$ & $99.42 \pm 6.21 \mathrm{~d}$ & $16.25 \pm 7.54^{\mathrm{a}}$ & $45.88 \pm 1.67^{\mathrm{b}}$ & $407.44 \pm 8.67^{\mathrm{c}}$ & $21.86 \pm 2.57^{\mathrm{d}}$ & $11.07 \pm 1.45^{\mathrm{e}}$ & $1.19 \pm 1.23^{\mathrm{d}}$ & $9.40 \pm 2.11^{\mathrm{c}}$ \\
\hline $25 \mathrm{WSC}$ & $98.13 \pm 8.43 d$ & $16.50 \pm 6.74^{\mathrm{a}}$ & $41.43 \pm 4.21^{\mathrm{b}}$ & $287.60 \pm 3.56^{\mathrm{e}}$ & $16.94 \pm 1.67 \mathrm{e}$ & $4.80 \pm 2.11^{\mathrm{f}}$ & $0.75 \pm 0.21^{\mathrm{e}}$ & $8.74 \pm 0.78^{d}$ \\
\hline $30 \mathrm{WSC}$ & $84.92 \pm 4.76 \mathrm{e}$ & $13.33 \pm 1.23^{\mathrm{c}}$ & $86.95 \pm 4.22^{\mathrm{a}}$ & $269.42 \pm 2.78^{\mathrm{e}}$ & $1.71 \pm 2.13^{\mathrm{f}}$ & $2.12 \pm 3.17^{\mathrm{g}}$ & $0.64 \pm 0.34^{\mathrm{f}}$ & $6.68 \pm 0.98^{e}$ \\
\hline
\end{tabular}

$\mathrm{CF}=$ control flooding; $\mathrm{CS}=$ control saturated; WSC, water stress cycle; \pm mean standard errors; means followed by different letters in a column differ significantly. 
plants with the highest plant height and 1000 grainweight. However, the tillers mortality rate also increase with increasing duration of water stress cycle. The increased yield of rice under short water stress cycle might be due to increased biomass, filled spikelet, 1000grain weight, total panicle and tillers number. The decrease of rice yield and plant morphology with increasing water stress was also observed by WAN et al. (2009). In the current study,it was observed that the biomass and filled spikelet was not effected for 5 days of irrigation difference, exceding this time, there would be reduction of the biomass and filled spikelet percentage and also reduce yield. Cyclic water stress had significant influence on chlorophyll contents in rice (Table 2). It was also observed that increased duration of water stress can significantly reduced total chlorophyll content as well as chlorophyll $\mathrm{a} / \mathrm{b}$ ratio and the similar result was also supported by a study from NILSEN \& ORCUTT (1996). Some previous research has also indicated that water stress increase the plant electrolyte leakage and thus reduce chlorophyll content in leaves (PETROV et al., 2012).

Water stress have significant effect on free proline and maliondialdehyde content in rice (Table 2). Proline and MDA content increased with the increased duration of water stress. According to BLACKMAN et al. (1995), the accumulation of free proline is an indication of reduced osmotic adjustment ability in plant due to water stress. Moreover, some previous reports claims that activation of pyrroline-5-carboxylate synthetase (an enzyme from proline biosynthesis) increased in longer drought period (SANADA et al., 1995). The formation of malondialdehyde (MDA) was considered as a measure of lipid peroxidation that was induced by water stress. MDA, a decomposition product of polyunsaturated fatty acids hydroperoxides, is a suitable biomarker for oxidative stress.

Water stress have significant effect on leaf gas exchange in rice variety MR220 (Table 3). It was also observed that there were no significant different between continuously flooding (CF) and continously saturated (CS) condition in net photosynthesis, transpiration rate, WUE and Fv/Fm values. Therefore it can be stated that rice variety MR220 do not require flooding irrigation as it is necessary for most of the traditional rice varieties. Water stress cycle reduced net photosynthesis by $5,10,16.8,21$, 27 and $62 \%$ for $5,10,15,20,25$ and 30 days of stress periods respectively when compared to continously flooding (CF). It was also observed that WUE was higher at 25 days of water stress cycle $(12.48 \mu \mathrm{mol})$, which reduceto $16.8 \%$ at 30 days of water stress cycle. Longer duration of stress would increase photochemical quenching of rice which cause decreased fv/fm value. Transpiration rate have positive correlation with net photosynthesis rate (Table 3 ). The similar result was also observed by other researchers in rice (CENTRITTO et al., 2009). Leaf gas exchange was always higher under flooding condition (CF) followed by saturated condition (CS) and lower water stress cycle. Stomatal responses has been associated with chemical signals, particularly to the synthesis of ABA, which regulate the rate of transpiration and plant moisture status (GRIGG et al., 2000). In the present study, rice growth under saturated and

Table 2 - The impact of cyclic water stress on chlorophyll contents, proline accumulation and lipid peroxidation in rice (var. MR220).

\begin{tabular}{|c|c|c|c|c|c|c|}
\hline $\begin{array}{l}\text { Water stress } \\
\text { treatments }\end{array}$ & $\begin{array}{l}\text { Chlorophyll a } \\
\left(\mathrm{mg} \mathrm{g}^{-1} \mathrm{FW}\right)\end{array}$ & $\begin{array}{l}\text { Chlorophyll b } \\
\left(\mathrm{mg} \mathrm{g}^{-1} \mathrm{FW}\right)\end{array}$ & Chl-a/chl-b & $\begin{array}{l}\text { Total } \\
\text { Chlorophyll } \\
\left(\mathrm{mg} \mathrm{g}^{-1} \mathrm{FW}\right)\end{array}$ & Free proline & $\begin{array}{l}\text { Lipid } \\
\text { peroxidation }\end{array}$ \\
\hline $\mathrm{CF}$ & $3.82 \pm 1.21^{\mathrm{a}}$ & $1.83 \pm 0.89^{\mathrm{a}}$ & $2.08 \pm 0.21^{\mathrm{b}}$ & $5.67 \pm 1.21^{\mathrm{a}}$ & $3.75 \pm 1.22^{\mathrm{f}}$ & $12.12 \pm 0.45^{\mathrm{e}}$ \\
\hline CS & $3.49 \pm 0.89^{\mathrm{a}}$ & $1.70 \pm 1.56^{\mathrm{b}}$ & $2.05 \pm 0.78^{\mathrm{b}}$ & $5.20 \pm 1.25^{\mathrm{a}}$ & $3.90 \pm 0.89^{\mathrm{e}}$ & $11.42 \pm 1.21^{\mathrm{f}}$ \\
\hline $5 \mathrm{WSC}$ & $3.02 \pm 1.24^{\mathrm{b}}$ & $1.66 \pm 1.45^{\mathrm{c}}$ & $1.81 \pm 0.89^{\mathrm{c}}$ & $4.69 \pm 0.89^{b}$ & $3.65 \pm 0.67^{\mathrm{d}}$ & $11.11 \pm 2.17^{\mathrm{f}}$ \\
\hline $10 \mathrm{WSC}$ & $3.19 \pm 2.21^{\mathrm{b}}$ & $1.60 \pm 1.32^{\mathrm{c}}$ & $1.83 \pm 1.21^{\mathrm{c}}$ & $4.79 \pm 1.12^{\mathrm{b}}$ & $3.81 \pm 0.87^{\mathrm{d}}$ & $24.21 \pm 1.31^{\mathrm{d}}$ \\
\hline $15 \mathrm{WSC}$ & $2.77 \pm 1.78^{\mathrm{c}}$ & $1.39 \pm 1.22^{\mathrm{d}}$ & $1.88 \pm 0.98^{\mathrm{c}}$ & $4.16 \pm 1.45^{\mathrm{c}}$ & $4.05 \pm 0.45^{\mathrm{c}}$ & $28.21 \pm 1.21^{\mathrm{c}}$ \\
\hline $20 \mathrm{WSC}$ & $2.68 \pm 2.34^{\mathrm{c}}$ & $1.28 \pm 0.78^{\mathrm{e}}$ & $1.88 \pm 0.21^{\mathrm{c}}$ & $3.96 \pm 0.89^{d}$ & $4.19 \pm 0.44^{\mathrm{b}}$ & $27.31 \pm 1.17^{\mathrm{c}}$ \\
\hline $25 \mathrm{WSC}$ & $2.53 \pm 1.78^{\mathrm{d}}$ & $1.14 \pm 0.67^{\mathrm{f}}$ & $2.21 \pm 1.21^{\mathrm{a}}$ & $3.62 \pm 0.78^{d}$ & $4.37 \pm 0.56^{\mathrm{b}}$ & $35.61 \pm 1.08^{\mathrm{b}}$ \\
\hline $30 \mathrm{WSC}$ & $2.13 \pm 1.22^{\mathrm{d}}$ & $1.04 \pm 0.45^{\mathrm{g}}$ & $2.01 \pm 1.76^{\mathrm{a}}$ & $3.12 \pm 0.67^{\mathrm{e}}$ & $5.31 \pm 0.76^{\mathrm{a}}$ & $44.16 \pm 0.98^{a}$ \\
\hline
\end{tabular}

$\mathrm{CF}=$ control flooding; $\mathrm{CS}=$ control saturated; WSC, water stress cycle; \pm mean standard errors means followed by different letters in a column differ significantly. 
Table 3 - The impact of cyclic water stress on different physiological activities and water use efficiency in rice (var. MR220).

\begin{tabular}{|c|c|c|c|c|c|}
\hline Treatments & $\begin{array}{l}\text { Net photosynthesis } \\
\left(\mu \mathrm{mol} \mathrm{m}{ }^{-2} \mathrm{~s}^{-1}\right)\end{array}$ & $\begin{array}{l}\text { Stomatal } \\
\text { conductance } \\
\left(\mathrm{mmol} \mathrm{m}^{-2} \mathrm{~s}^{-1}\right)\end{array}$ & $\begin{array}{l}\text { Transpiration rate } \\
\left(\mathrm{mmol} \mathrm{m}^{-2} \mathrm{~s}^{-1}\right)\end{array}$ & $\begin{array}{l}\text { Instantaneous } \\
\text { water use efficiency } \\
\text { (iWUE) }\end{array}$ & $\begin{array}{l}\text { Chlorophyll } \\
\text { fluorescence } \\
\left(\mathrm{f}_{\mathrm{v}} / \mathrm{f}_{\mathrm{m}}\right)\end{array}$ \\
\hline $\mathrm{CF}$ & $11.42 \pm 1.12^{\mathrm{a}}$ & $25.48 \pm 2.12^{\mathrm{b}}$ & $1.83 \pm 3.11^{\mathrm{a}}$ & $6.11 \pm 2.13^{\mathrm{e}}$ & $0.78 \pm 0.03^{\mathrm{a}}$ \\
\hline $\mathrm{CS}$ & $11.61 \pm 0.98^{\mathrm{a}}$ & $26.01 \pm 2.14^{\mathrm{a}}$ & $1.87 \pm 2.76^{\mathrm{a}}$ & $6.21 \pm 2.15^{\mathrm{e}}$ & $0.78 \pm 0.13^{\mathrm{a}}$ \\
\hline $5 \mathrm{WSC}$ & $10.80 \pm 1.23^{b}$ & $26.27 \pm 1.43^{\mathrm{a}}$ & $1.38 \pm 1.76^{\mathrm{b}}$ & $7.81 \pm 3.12^{\mathrm{d}}$ & $0.77 \pm 0.02^{\mathrm{a}}$ \\
\hline $10 \mathrm{WSC}$ & $10.28 \pm 0.87^{b}$ & $24.46 \pm 2.54^{\mathrm{c}}$ & $1.15 \pm 2.54^{\mathrm{c}}$ & $8.92 \pm 1.16^{\mathrm{c}}$ & $0.76 \pm 0.32^{\mathrm{b}}$ \\
\hline $15 \mathrm{WSC}$ & $9.65 \pm 1.23^{\mathrm{c}}$ & $22.14 \pm 1.65^{\mathrm{d}}$ & $1.06 \pm 3.11^{\mathrm{d}}$ & $9.12 \pm 2.15^{\mathrm{c}}$ & $0.74 \pm 0.41^{\mathrm{b}}$ \\
\hline $20 \mathrm{WSC}$ & $8.97 \pm 0.97^{\mathrm{d}}$ & $20.22 \pm 1.54^{\mathrm{e}}$ & $0.98 \pm 4.12^{\mathrm{e}}$ & $9.18 \pm 2.67^{\mathrm{c}}$ & $0.71 \pm 0.45^{\mathrm{b}}$ \\
\hline $25 \mathrm{WSC}$ & $8.26 \pm 1.23^{\mathrm{e}}$ & $18.77 \pm 1.76^{\mathrm{f}}$ & $0.68 \pm 3.11^{\mathrm{f}}$ & $12.48 \pm 2.11^{\mathrm{a}}$ & $0.69 \pm 0.41^{\mathrm{c}}$ \\
\hline $30 \mathrm{WSC}$ & $4.29 \pm 1.56^{\mathrm{f}}$ & $7.92 \pm 1.89^{\mathrm{g}}$ & $0.37 \pm 2.14^{\mathrm{g}}$ & $10.38 \pm 0.78^{b}$ & $0.65 \pm 0.63^{\mathrm{c}}$ \\
\hline
\end{tabular}

$\mathrm{CF}=$ control flooding; $\mathrm{CS}=$ control saturated; WSC, water stress cycle; \pm mean standard errors; means followed by different letters in a column differ significantly.

flooding condition, showed a consistent increase in photosynthesis rate, stomatal conductance and water use efficiency.

Cyclic water stress has remarkable effect on soil moisturecontent, RWC in leaves and water productivity in rice (Table 4). Generally soil moisture and relative water content was higherunder $\mathrm{CF}$ which reduced to $73,70,68,60,20$, and $16 \%$ for $30,25,20,15,10$ and 5 days of irrigation cycle respectively. This showed that maintaining high soil moisture can also enhance RWC in leaves and water productivity of rice (KUDOYAROVA et al.)

\section{CONCLUSION}

The results of the present study have indicated that the increase of water stress cycle reduces yield of rice. It was also found that proline accumulation and maliondialdehyde contents in leaves increased and chlorophyll content reduced with increased duration of water stress cycle. It was observed that the biomass and filled spikelet is not effected for 5 days of irrigation difference, exceding that time, it would reduce the biomass and filled spikelet percentage and also reduce yield. Therefore it can be stated that rice variety MR220 do not require flooding irrigation as it is necessary for most of the traditional rice varieties, whereas irrigation cycle of 5 days intervel is more appropriate to increase water use and higher yield for rice variety MR220.

\section{ACKNOWLEDGEMENTS}

We wish to acknowledge Ministry of Education (MOE), Malaysia for Long-term Research Grant Scheme (LRGS) (Food Security: Enhancing sustainable rice production) and Universiti Putra Malaysia for funding this research project and technical supports.

Table 4 - The impact of cyclic water stress on soil moisture, relative water contents and water productivity of rice (var. MR220).

\begin{tabular}{lccc}
\hline Water stress treatments & Soil moisture $(\%)$ & Relative water content $(\%)$ & Water productivity $\left(\right.$ kg L $\left.{ }^{-1}\right)$ \\
\hline CF & $82.40 \pm 1.23^{\mathrm{a}}$ & $81.40 \pm 9.87^{\mathrm{a}}$ & $4.41 \pm 2.33^{\mathrm{a}}$ \\
CS & $67.86 \pm 2.22^{\mathrm{b}}$ & $78.84 \pm 2.34^{\mathrm{a}}$ & $4.63 \pm 3.11^{\mathrm{a}}$ \\
$5 \mathrm{WSC}$ & $66.15 \pm 3.32^{\mathrm{b}}$ & $70.51 \pm 5.76^{\mathrm{b}}$ & $3.67 \pm 4.21^{\mathrm{b}}$ \\
$10 \mathrm{WSC}$ & $59.67 \pm 4.11^{\mathrm{c}}$ & $66.51 \pm 6.81^{\mathrm{c}}$ & $3.51 \pm 3.23^{\mathrm{c}}$ \\
$15 \mathrm{WSC}$ & $55.57 \pm 4.54^{\mathrm{c}}$ & $64.95 \pm 7.22^{\mathrm{c}}$ & $1.76 \pm 4.21^{\mathrm{d}}$ \\
$20 \mathrm{WSC}$ & $50.49 \pm 5.21^{\mathrm{d}}$ & $55.10 \pm 5.23^{\mathrm{d}}$ & $1.41 \pm 3.44^{\mathrm{e}}$ \\
$25 \mathrm{WSC}$ & $40.99 \pm 1.23^{\mathrm{e}}$ & $50.30 \pm 4.12^{\mathrm{e}}$ & $1.31 \pm 1.32^{\mathrm{f}}$ \\
$30 \mathrm{WSC}$ & $27.69 \pm 2.43^{\mathrm{f}}$ & $36.10 \pm 3.42^{\mathrm{f}}$ & $1.15 \pm 1.34^{\mathrm{g}}$ \\
\hline
\end{tabular}

$\mathrm{CF}=$ control flooding; $\mathrm{CS}=$ control saturated; WSC, water stress cycle; \pm mean standard errors $\mathrm{n}$; means followed by different letters in a column differ significantly. 


\section{REFERENCES}

AUGE, R.M.; MOORE, J.L. Stomatal response to non-hydraulic root- to-shoot communication of partial soil drying in relation to foliar dehydration tolerance. Environmental and Experimental Botany, v.47, p.217-229, 2002. Available from: < http://dx.doi. org/10.1016/S0098-8472(01)00129-0>. Accessed: May 2002. doi: 10.1016/S0098-8472(01)00129-0.

BAJJI, M. et al. Water deficit effects on solute contribution to osmotic adjustment as a function of leaf ageing in three durum wheat (Triticum durum Desf.) cultivars performing differently in arid conditions. Plant Science, v.160, n.4, p.669-681, 2001. Available from: <http://dx.doi.org/10.1016/S0168-9452(00)00443-X>. Accessed: March 2001. doi: 10.1016/S0168-9452(00)00443-X.

KUDOYAROVA, G.R. et al. Effect of partial rootzone drying on the concentration of zeatin-type cytokinins in tomato (Solanum lycopersicum L.) xylem sap and leaves. Journal of Experimental Botany, v.58, n.2, p.161-168, 2007. Available from: <http://jxb oxfordjournals.org/content/58/2/161>. Accessed: September 2006. doi: $10.1093 / \mathrm{jxb} / \mathrm{erl116}$.

BLACKMAN, S.A. et al. Desiccation tolerance in developing soybean seeds: the role of stress proteins. Physiologia Plantarum, v.93, p.630-638. 1995. Available from: <http://onlinelibrary.wiley. com/doi/10.1111/j.1399-3054.1995.tb05110.x/full>. Accessed: April 2006. DOI: 10.1111/j.1399-3054.1995.tb05110.x.

BOUMAN, B.A.M.; TUONG, T.P. Field water management to save water and increase its productivity in irrigated lowland rice. Agricultural Water Management, v.49, n.1, p.11-30, 2001. Available from: <http://www.sciencedirect.com/science/article/pii/ S0378377400001281>. Accessed: July 2001. doi: 10.1016/S03783774(00)00128-1.

CENTRITTO, M. et al. Leaf gas exchange, carbon isotope discrimination, and grain yield in contrasting rice genotyppes subjected to water deficit during the reproductive stage. Journal of Experimental Botany, v.60, n.8, p.2325-2339, 2009. Available from: <http://jxb.oxfordjournals.org/content/early/2009/05/14/jxb. erp123>. Accessed: May 2009. doi: 10.1093/jxb/erp123.

DERE, S. et al. Spectrophotometric determination of chlorophyll - A, B and total carotenoid contents of some algae species using different solvents. Turkish Journal of Botany, v.22, p.13-17, 1998. Available from: <http://journals.tubitak.gov.tr/botany/ issues/bot-98-22-1/bot-22-1-3-96040.pdf>.

GRIGG, B.C. et al. Rice responses to changes in flood water and $\mathrm{N}$ timing in southern USA. Field Crops Research, v.66, n.1, p.73-79, 2000. v. 66, n. 1, p. 73-79, 2000, Available from: <http://www.sciencedirect.com/science/article/pii/
S0378429000000654>. Accessed: April 2000. doi: 10.1016/ S0378-4290(00)00065-4.

HUKE, R.E.; HUKE, E.H. Rice area by type of culture. In: South, Southeast and East Asia, a revised and updated data base. Philippines: International Rice Research Institute, Manila: 1997.

ISLAM, M.R. et al. Effects of water-saving superabsorbent polymer on antioxidant enzyme activities and lipid peroxidation in oat (Avena sativa L.) under drought stress. Journal of the Science of Food and Agriculture, v.91, n.4, p.680-686, 2011. Available from: <onlinelibrary.wiley.com/doi/10.1002/jsfa.4234/pdf>. Accessed: December 2010. doi: 10.1002/jsfa.4234.

NAHER, U.A. Techniques of efficient fertilizer management for wetland rice- a review. Australian Journal of Crop Science, v.5, n.12, p.1661-1669, 2011. Available from: <http://www.cropj.com/ naher2_5_12_2011_1661_1669.pdf>.

NILSEN, E.T.; ORCUTT, D.M. Physiology of plants under stress. Abiotic factors. 2.ed. New York: John Wiley and Sons 1996. p.689.

PETROV, P.I. Ion leakage and leaf anatomy of barley plants subjected to dehydration. Genetics And Plant Physiology, v.2, n.2, p.15-23, 2012. Available from: <http://www.bio21.bas.bg/ ippg/bg/wp-content/uploads/2012/12/GPP_2_1-2_15-231.pdf >.

SANADA, Y. et al. Novel light-dark change of proline levels in halophythe (Mesembryanthemum crystallinum L.) and glycophytes (Hordeum vulgare L. and Triticum aestivum L.): Leaves and roots under salt stress. Plant Cell Physiology, v.36, p.965-970, 1995. Available from: <http://pcp.oxfordjournals.org/ content/36/6/965.full.pdf $>$. Accessed: May 1995.

SUSANA, E. Et al. Simulation of stomatal conductance for Aleppo pine to estimate its ozone uptake. Environmental Pollution, v. 146, p. 617-623, 2007. Available from: <http://www.sciencedirect. com/science/article/pii/S0269749106004878>. Accessed: April 2007. doi: 10.1016/j.envpol.2006.08.008.

WAN, M.Z. et al. Rice growth and yield under rain shelter house as influenced by different water regimes. International Journal of Agriculture and Biological science, v.11, p.556560, 2009. Available from: <www.fspublishers.org/published papers/82613_..pdf>.

YAMAKAWA, $\mathrm{H}$. et al. Comprehensive expression profiling of rice grain filling-related genes under high temperature using DNA microarray. Plant Physiology, v.144, p.258-277, 2007. Available from: <http://www.plantphysiol.org/content/144/1/258.long>. Accessed: May 2007. doi: 10.1104/pp.107.098665. 